\begin{tabular}{|l|l|l|}
\hline Volume 17 & No. 1, Mei 2021 & Halaman 1-13 \\
\hline
\end{tabular}

\title{
GRAMMATICAL SHIFTING OF DETERMINER PHRASE IN TRANSLATION OF DRAMA MACBETH AS THE RESULT OF USING TRANSLATION TECHNIQUE \\ (Perubahan Struktur Gramatikal Frasa Determiner dalam Teks Terjemahan Drama Macbeth sebagai Dampak Penggunaan Teknik Penerjemahan)
}

\author{
Firda Zuldi Imamah \& Agus Subiyanto \\ Diponegoro University
}

Jalan Prof. Sudarto, S.H. Semarang, Indonesia

Pos-el: firdazuldi@gmail.com; subaling@gmail.com

(Diterima: 28 Februari 2020; Direvisi: 13 Juli 2020; Disetujui: 16 November 2020)

\begin{abstract}
Abstrak
"Macbeth" adalah salah satu karya sastra dari penulis Shakespeare yang memiliki penyampaian ekspresi yang memiliki referensi konseptual yang kompleks. Ekspresi tersebut salah satunya ada dalam frasa determiner. Penggunaan teknik penerjemahan cukup memengaruhi perubahan struktur gramatikal frasa determiner. Penelitian ini bertujuan untuk mengidentifikasi pola pergeseran struktur gramatikal yang terjadi pada hasil terjemahan frasa determiner dalam drama "M acbeth" yang merupakan akibat dari dampak penggunaan teknik terjemahan. Penelitian ini adalah penelitian kualitatif deskriptif. Data penelitian merupakan 50 frasa determiner dan versi terjemahan Indonesianya. Data tersebut diambil dari naskah drama Bahasa Inggris sebagai teks bahasa sumber dan teks bahasa sasaran diambil dari versi terjemahannya. Hasil penelitian menunjukkan bahwa ada tiga bentuk pergeseran tata bahasa yaitu pelesapan, penambahan dan perubahan bentuk adjung bahasa sumber. Pergeseran ini umumnya karena sistem tata bahasa yang berbeda dari dua bahasa dan secara khusus juga disebabkan oleh penggunaan tiga belas teknik terjemahan. Teknikteknik tersebut meliputi adaptasi, kompensasi, reduksi, partikulasi, generalisasi, kesepadanan lazim, modulasi, kalke, transposisi, amplifikasi, kompilifikasi linguistik, kreasi diskursif, dan kompresi linguistik. Teknik yang menyebabkan penghilangan adalah reduksi, kompresi linguistik, transposisi, adaptasi, dan partikulasi. Bentuk penambahan disebabkan oleh teknik amplifikasi, modulasi, generalisasi, dan amplifikasi. Teknik yang menyebabkan perubahan bentuk adjung adalah kreasi diskursif.
\end{abstract}

Kat-kata kunci: teknik penerjemahan, pergeseran struktur, frasa determiner, drama

\section{Abstract}

"Macbeth" is one of Shakespeare's works that has deeper conceptual references to expression. Those expression were well delivered in the determiner phrases. The translation techniques use gave impact to the grammatical shift of the phrases. This study aims to discuss the patterns of grammatical structure shift that happened on the translation of determiner phrases in the drama "Macbeth" as the impact of using certain translation techniques. This study is a descriptive qualitative research. The data are 50 determiner phrases and their translated version in Bahasa Indonesia. Those data are taken from an English drama manuscript the source text, and the target text are retrieved from the translated version. The result shows that there are three forms of grammatical shift which are omission, addition and the shift of source language adjunct. These shifts were generally caused by different grammatical system of the two languages and specifically caused by the use of thirteen translation techniques. The techniques include adaptation, compensation, reduction, particularization, generalization, established equivalent, modulation, calque, transposition, amplification, linguistic amplification, discursive creation, and linguistic compression. The techniques that caused omission are reduction, linguistic compression, transposition, 
adaptation and particularization. The addition was caused by amplification, modulation, generalization, and amplification technique. The technique that caused the shift of adjunct is discursive creation.

Keywords: translation technique, translation shift, determiner phrase, drama

DOI: $10.26499 / j k . v 17 i 1.2228$

How to cite: Imamah, F. Z., Subiyanto, A. (2021). Grammatical shifting of determiner phrase in translation of drama Macbeth as the result of using translation technique. Kandai, 17(1), 1-14 (DOI: 10.26499/jk.v17i1.2228)

\section{INTRODUCTION}

Translation has been an interesting discussion among researchers for its relation to language contact between two or more languages. The works related to it, including the grammatical structure shift, are being one of the focuses. The shift that happened in the translation process is caused by several reasons. Besides the grammatical level gaps between two languages, the use of translation technique is also shown in the result of translation. Translation technique is one of many ways for translators to help transfer the ideas and information from one language to another language's closest meaning. This article was written for the issue which is about the impact of translation technique use on the grammatical structure shift.

The play Macbeth was written by the famous William Shakespeare in the middle of $17^{\text {th }}$ century. The interesting part of this artwork is that a simple phrase that consist of a determiner, adjective and noun could hold a whole scene and emotion. Shakespeare used many idiomatic and metaphoric words that were amazingly combined even though they are not the usual collocation the reader would see. A play emphasizes the expressive and informal style of writing (Newmark, 1998). Instead of the usual long narrative explanation of a scene, Shakespeare could make two or three words that embrace everything in it. He could give the reader the art of implicitness or bring the most contrast thing to describe an irony of a situation. As the translation process done, there are different patterns of shift appeared that the discussion should put a concern on it. It was stated before how in this play even a word could hold a lot of meaning to the essentials of the story, and a slight or big change toward it would give different meaning. The fact that this is a play that has possibility to be performed and involved acting makes the grammatical structure shift cannot be ignored. The researcher found a phenomenon in which different results appears when translating determiner phrases on the play. It is intriguing to find the reason how the phrase with the same structure could be translated variously and caused its purposive meaning slightly or significantly change. A phrase written as "the everlasting bonfire" would be translated into "neraka". Another phrase written as "thy undaunted mettle" would be translated into "jiwamu yang pemberani". These two examples show a brief view of how this was beyond different system of grammatical between source language (SL) and target language (TL). The behind process of translation process by using certain translation technique was also involved in it. Thus, this research identifies the shift happened in the determiner phrases translation and how the certain translation technique could impact those grammatical shifts.

The previous works which also emphasized on the grammatical structure shift have discussed different focuses and results. The objects of the studies also vary from word up to sentence level. Some of them identified on the 
meaning equivalence after the shift happened. The further identification went to the translation assessment and quality. Dewi, Indrayani, \& Citraresmana (2014) stated that the shift happened in the adjective phrases in the English magazine to Indonesian could be devided into $72 \%$ equivalence and $28 \%$ not equivalence. They focused on the semantic level of shift thus the result further showed the equivalence divided into textual and dynamic. Semantic level is the easiest way to tell the existence of shift in the result of translating. Another work that focused on the contextual matter was Silalahi (2016) who identified the translation of verb from English to Indonesian and found that between SL and TL essential function of verb, the translator relied on the contextual meaning. There was also a work done meticulously by Munif (2008) who found the translation shift on the meaning and structure. Those two cases were concluded in the discussion of how the translation result was accurate enough or inaccurate. The accuracy fell on the quantitative analysis and showed the calculation in percentage. The accuracy of translated text was also an interesting topic to talk about translation shift further. The accuracy is one of the key to quality assessment of a translation work. The work was done by Firdaus (2014) with a finding that said relative clause translation had showed shift from its semantic level as the cause of translation technique use. The next research is a dissertation written by Nurhaniah (2008) which examined interrogative in conversations in a teenage novel entitled Dear No Body. The purpose of this research is to identify the interrogative, the pragmatic function of the interrogative and the analysis of the equivalence of the interrogative. Rafi'ie, Pastika, \& Malini (2018) discussed the translation of reduplication text. The purpose of this study is to analyze the equivalence of reduplication in translated text. Data is taken from The Magic English textbook and its translation in Indonesian. Wulandari (2017) used the perspective of LSF theory. She talked about changes in the complex paratactic clause are caused by the use of the translation techniques. The translation techniques are transposition, amplification, and amplification of linguistics. This study aims to find shifts that occur in complex clauses in the novel "The Snow of Kilimanjaro" and the translated text in Indonesian.

None of the previous works have put more attention on the significance of the grammatical loss or gain of the translated text and how far the translation technique could impact the structure shift of the text they analyzed. This research stands on these matters as the purpose of the study. Therefore, the purpose of this research is to identify the patterns of shift of grammatical structure of determiner phrases in the translated text of drama "Macbeth" as the result of translation techniques use.

\section{THEORETICAL FRAMEWORK}

Three main theories of this research are translation shift, translation techniques and determiner phrase.

\section{Translation Theory}

Catford (1965) said that translation is the process of replacing the textual elements of the source language with the equivalent textual elements of the target language. Translation is an attempt to replace a written message in one language with a message that is equal in another language (Newmark, 1998). In other words, the success of a translation process requires an understanding of 
aspects of the source language and target language.

In translating types of expressive discourse such as drama texts, translation at the unit level does not occur much because vocabulary can contain complete meaning (Newmark, 1998). This means that translation of drama is usually done by taking idea of one full speech or sentence rather than word by word. Translators must prioritize the essence of drama for general readers and students, so translators must maintain the text to feel natural when staged on the stage with the target language. (Newmark, 1998).

\section{Translation Technique}

Molina and Albir (2002) divided translation techniques into eighteen types which are considered in accordance with the phenomenon of change that exists in the drama text of Macbeth. The eighteen techniques are adaptation, compensation, reduction, particularization, generalization, established equivalent, modulation, calque, transposition, amplification, linguistic amplification, discursive creation, and linguistic compression, literal, borrowing, variation, substitution and description.

\section{Translation Shift}

Grammatical structure shifts are divided into two types namely level shifting and category shifting (Catford, 1965). Level shift is a linguistic level component of the source language that has different levels in the target language. This shift occurs when a language level in one language has an equivalent translation at a level that is not the same in another language. For example, translation between phonological and morphological levels or between grammatical and lexical levels cannot occur. Level changes can be made possible between changes from grammatical to lexical or vice versa. For example, the translation of the sentence "he runs fast" which changes to "dia berlari dengan cepat" shows that the lexical fast is translated into a prepositional phrase consisting of prepositions 'dengan' and adjectives 'cepat'.

The second type is category shift which includes level shift, category or word class shift and structure shift. Category shift is a shift that occurs when categories in a source language have different forms or are in different positions in the target language. Level shift occurs when the unit elements in the source language have equivalent unit elements that are not the same in the target language. Word class shift occurs when there is a change in grammatical categories of a source language element to the target language (Catford, 1965). Structure shifts occur when elements of the source language undergo changes in grammatical order or structure after being translated into the target language.

\section{Determiner Phrase and X-Bar Theory}

Determiner phrases are phrases with determiner as the head. The head relates to the position of a word. The head is determiner because the position of the proposition is occupied by the determiner. In determiner phrases, nouns can be complements and adjective can be adjunct.

Determiner phrases with noun phrase as a complement rise an argument about the position of the head of the phrase. Newson, et al., (2006) explained that although nouns are semantically more prominent elements in the structure of phrase, it cannot be denied that we cannot use semantic properties to infer 
syntactic properties. Determiners in English include articles, demonstrative, possessive, numerical, classifiers, and others. Meanwhile the complement and adjunct can be projected with nouns or adjectives. Determiners have two functional head choices, which is having noun phrases as complement, or not having complement (Newson, et al., 2006).

Newson, et al., (2006) defined Xbar theory as a theory of the arrangement of complement, specifier, and adjunct. He explained that the complement is the sister of the head and always follows the head. The specifier is the sister to $\mathrm{X}^{\prime}$ and daughter of XP. The specifiers precede the head and are restricted to one per phrase. Both complement and specifier are restricted by the property and the meaning of the head. The adjunct can be placed at any X-bar level such as $\mathrm{X}, \mathrm{X}^{\prime}$ and XP. The adjunct expands the level which it adjoined to. Any number of adjuncts can be added to a structure and the process is recursive.

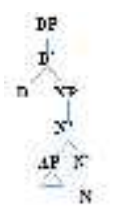

Determiner Phrase consists of head, adjunct and complement

The structure tree of determiner phrase above shows the X-Bar structure of determiner phrase which consists of a head, adjunct and complement. X-Bar structure can be applied universally. The basic concept of each component has patent role and function. The difference of its application in English and Indonesian locates at the position of the adjunct.

Indonesian has a variety of phrases in the form of noun phrases, adjective phrases, pronouns phrases, prepositional phrases, number phrases, predicate phrases, and reflexive phrases (Sneddon,
1996). In Indonesian determiner phrases, determiner also be the head of certain elements. These elements include demonstrative, quantifiers, numbers, and classifiers.

\section{RESEARCH METHODS}

This study is a descriptive qualitative research. The data were taken from two main sources which were the script of the drama for the source text and the translated version for the target text. The source text was retrieved from online Shakespeare's work at (Mabillard, 2020) Meanwhile the target text was obtained from the translated version that was already published in a form of a book by Narasi publishing company. The data are fifty determiner phrases that specifically has structure consisting of determiner, adjective and noun. They were taken by documentation method and sorted by note taking technique. There are 5 acts and each act consists of 3 up to 8 scenes. The note taking was done per scene by using purposive sampling method. The method of data analysis was done by doing categorical indexing. This study makes categorization from the data and uses comparative method to analyze the shift that happened from source language to target language. X-bar Theory is used to further analysis of grammatical shift in phrases.

\section{DISCUSSION}

The determiner phrases in this drama generally consist of head, adjunct, and complement. The adjunct encompasses categories of adjectives and adverbs. The phrase structure of the source language generally consists of determiners, adjective, and nouns. The determiner phrases are composed of determiner of articles, possessive, 
demonstrative, and quantifier. The next component is the adjunct which consists of adjectival adjunct and adverbial adjunct. The last component is the complement which is a noun. In this study, two almost identical terms are used: complement and complementizer phrase. The term complement is used when referring to one of the components of the X-Bar structure. Meanwhile, the complementizer phrase is one of the results of changes in the form of phrases with the head "yang" in the target language phrases. The form of changes that occurs in determiner phrases includes the form of omission, addition and shift of adjunct and complement.

\section{The Omission Pattern}

Table 1 shows how frequent the shift of each omission happened. The omission of adjectival adjunct and head occur the most compared to the others. This shift implied that the complement is one component that the translator considers as the main point of the phrase. The other two components have had an influence from the use of translation technique. The omission leads to the component to be the head in the target text phrase unless there is no other shift happened that restrains the component to be the head.

Table 1

Omission on the Determiner Phrase Translation

\begin{tabular}{l|c}
\multicolumn{1}{c|}{ Type of Shift } & $\begin{array}{c}\text { Percentage } \\
(\mathbf{\%})\end{array}$ \\
\hline Adjectival adjunct omission & $24 \%$ \\
\hline $\begin{array}{l}\text { Adjectival adjunct and head of } \\
\text { DP omission }\end{array}$ & $55 \%$ \\
\hline Head of DP omission & $21 \%$ \\
\hline
\end{tabular}

The omission of adjectival adjunct also happened frequently because the process of reducing the information on the adjective. This process results in the loss of the expressive value of the phrase. Some expressive and aesthetic values have a significant impact on the difference in information conveyed because the drama is a literary work that emphasizes that value. Thus, the shift that occurs in a component causes different effects on the remaining components. The essence of each component of the source language is very dense and has an important role. In other words, the description or depiction of a setting that can generally be described narratively in literary works such as novels or short stories, is compressed in the form of these phrases. In addition, the author used a lot of metaphors in writing the phrase. Thus, the omission that occurs in these components in the translation version gives a different meaning to the audiovisual interpretative sense of the readers.

\section{The Omission of Adjectival Adjunct}

The adjectival adjunct cannot be translated naturally nor has a coherent with the noun. In this drama, there are many combinations of adjectives and nouns that are not easily interpreted literally. Thus, the translator omitted the adjective as the choice. It shows in the following quotation and picture.

SL: Be these juggling fiends no more believed

TL: aku sudah tak mempercayai para $\underline{\text { iblis }}$

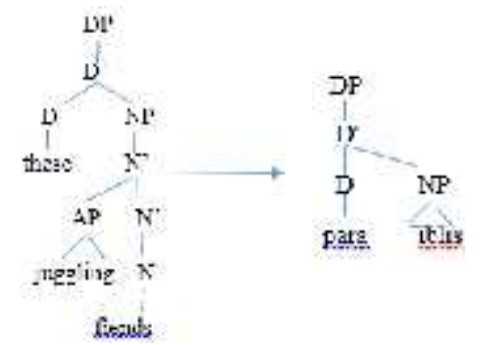

Figure 1 Omission of Adectival Adjunct

The former quotation shows the comparative view of how the text is 
transferred from English to Indonesian, and how the structure shift happened. The omission of adjective is the force of incoherent combination of adjective and noun. The adjective is supposed to apply to modify inanimate. These kinds of adjective are omitted by using reduction technique.

Another circumstance shows how adjective had been omitted directly even though it had coherence with the noun.

SL: Are you so gospelled to pray for this good man?

\section{TL: apakah kalian hanya akan duduk} dan mendoakan orang ini?

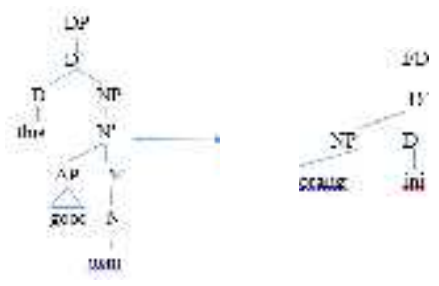

Figure 2 Omission of Adjectival Adjunct 2

The direct omission happened on the adjective without involving other components to compress their information. This shift purely reduces the information on the adjective value. The missing value caused the loss of the description of the said character.

\section{The Omission of Adjectival Adjunct and Head}

In some cases, there could be more than one component that could be omitted. Omission of two components that are also commonly found in the text of this translation is the adjunct and the head. The type of the adjunct is adjectival adjunct. Conditions might exist explaining how and why these components are lost.

First, the two components are lost when the other components are translated as the essence of the target language phrases. In other words, determiner and adjunct can be omitted when the noun will change its role as the head of the target language phrase. The missing component provides a piece of information that can help the translator determine the lexical reconstruction of the target language.

SL: The crow makes wing to the rooky wood

\section{TL: burung gagak sudah kembali ke dalam hutan}

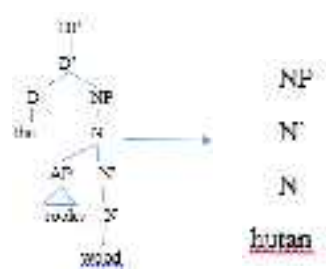

Figure 3 Omission of Adjunct and Head

The phrase is supposed to understand as the crow comes back to its home in the wood. The adjective refers to the bird and all that sums up to the home of the bird. The omission of two components shows how the transformation adjusts the textual of the complement. The complement gave the translator away to transfer it without being out of context. Even though there is missing points where specific place of the bird habitat could be delivered instead the common forest as the target text conveyed.

The omission of the components could not happen unless the two has similar distribution of meaning. The following quotation and figure show how the shift happened.

SL: we are sent to give thee from our royal master thanks

TL: Raja mengirim kami untuk menyampaikan rasa terimaksihnya 


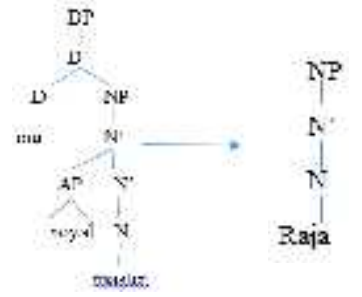

Figure 4 Omission of Adjunct and Head

The noun and the adjective on figure 4 have common distribution of meaning and are closely related. The noun could only be the common superior and the adjective was the one that categorize the noun as something more specific. The superior and royal was rebranded as one word as a king.

\section{The Omission of Head}

The third form of omission is the process of translating which involving the reduction of the head itself. It is easy enough to tell that the head of the phrase did not carry as much as what other components do. It does not mean that the head does not bring vital value to the phrase since the determiners of the phrase are those that give definite classification ahead of other components. The head omission occurs $21 \%$ of the overall data which is less than the other form of omission. The head's important role also shows as it could only be omitted when the adjunct of the phrase transform into complementizer phrase in target text. The head could not be omitted alone. The following example gives a view how the head could not be omitted unless the adjunct has further process to go.

SL: the poor country shall have more vices than it had before

\section{TL: negeri yang malang akan}

mengalami bencana yeng lebih buruk dari pada yang sebelumnya

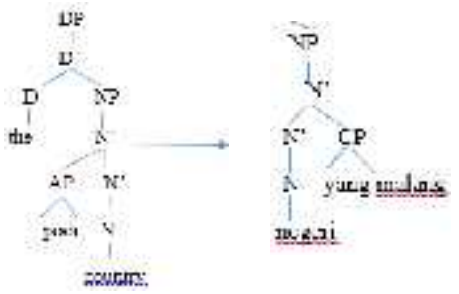

Figure 5 Omission of Head

The head omission on the figure 5 seems to omit the definite classification of the said country. There is no definite categorization as the noun falls to be common country. The transformation makes it seems like the character refers to tell a fortune. It clearly changed the point of view. The adjunct transformation as the prerequisite process only shows the different system of writing a noun and adjective in the two languages. This study has not found the further stance of this prerequisite process as the continuation of the omission process itself.

The reader might be curious if the omission of the head only significantly changed the point of view since it was the article "the" that was omitted. Another case appears where the determiner is a possessive one.

SL: nor our strong sorrow upon the foot of of motion

TL: dan belum tiba waktunya untuk menunjukan duka yang dalam

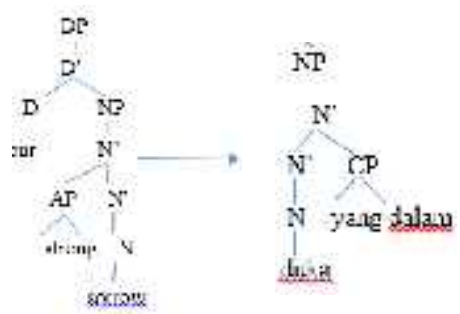

Figure 6 Omission of Head

The omission of the head in the figure 6 shows that the loss of possessive determiner impacts on the loss of selfproclaimed. The omission sounds like a 
narrative or that the character does not have the reference to themselves as the actors.

\section{The Addition of Adjunct}

The second form of shift is the addition of adjunct on the target text phrase. The researchers found that the addition of adjunct to the structure of the target language phrase is caused by several things or there are several conditions that explain how the addition of the component occurs. The addition of adjunct can occur because the target language does not have equivalent grammatical words thus translators need to add the information that provide the solution by adding component. There is only $6 \%$ addition in total from the overall data.

Table 2

Addition of Adjunct

\begin{tabular}{l|c}
\hline \multicolumn{1}{c|}{ Type of Shift } & $\begin{array}{c}\text { Percentage } \\
(\%)\end{array}$ \\
\hline Adjectival adjunct addition & $2 \%$ \\
\hline Prepositional adjunct addition & $4 \%$ \\
\hline
\end{tabular}

The $6 \%$ addition includes addition of the adjectival adjunct and prepositional adjunct. These two types of addition only happened in a small amount since expansion is harder to find rather than reduction of information at translation.

\section{The Addition of Prepositional Adjunct}

The addition of prepositional adjunct in the target language phrases aims to add information. The following quote shows that the translator added the prepositional phrase to complete an analogy which translator made of the reconstruction back from the translation of the determinant phrase of the source language.
SL: "new horrors come upon him like our strange matters"

TL: Macbeth belum terbiasa dengan gelar barunya seperti baju yang aneh di tubuhnya

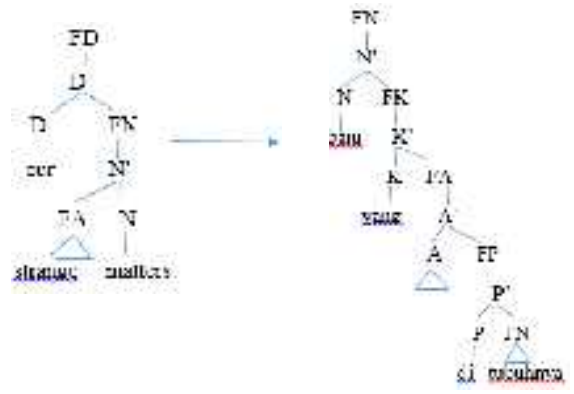

Figure 7 Addition of Prepositional Phrase

We assumed that the translator added prepositional adjunct because the translator intended to provide information to clarify the analogy that was created. The analogy refers to the translation of the "matters" complement as a strange outfit because the analogy is considered as the explanation that most closely matches the information presented by the author. To complete the information in accordance with the source language, the translator added prepositional phrases to the target language.

\section{The Addition of Adjectival Adjunct}

Adding adjectival adjunct to the target language can be seen from the presence of a new adjective in the structure phrase of the target language. The addition in the following data is a minimal form of description made by the translator of the implicit term used by the author.

SL: "What not put upon his spongy officers shall bear the guilt of our great Quell"

TL: Apapun yang kita lakukan bisa menyalahkan semuanya kepada pengawal bodoh yang mabuk itu 


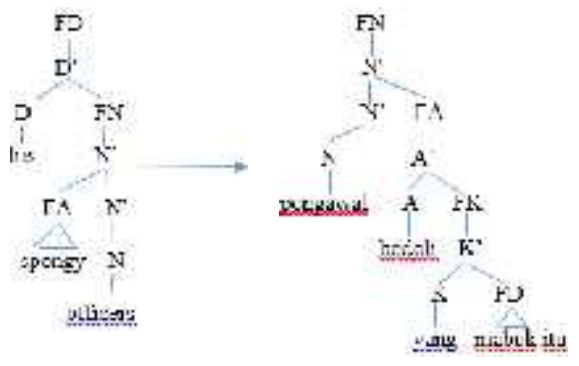

Figure 8 Addition of Adjectival Adjunct

The adjunct of the source language changes to the complementizer phrase. The substitution of meaning refers to the source language adjunct which is not normally used to describe a person. The addition by using the word "mabuk", the translator gives an additional description of "bodoh" to adjust the context of the text. This type of change can also be included in the type of adjunct shift to the complementizer phrase, but researchers make this part of adding individual components to the target language phrases because the addition of adjunct is in the main structure of the target language phrase, not in the complementizer phrase structure.

\section{The Shift of Adjunct}

The adjunct could transform into complementizer phrase and complement. The first transformation shows the shift that happened in the overall data along with the adjectival adjunct omission. There is an interesting point of the first transformation. This study could have included the shift to the change from adjunct to TL adjunct or complement as the others categorization. However, the transformation into complementizer phrase deserves its own place to discuss due to these few reasons. First, the change constitutes the different system of writing noun and adjective in both languages. Grammatically, despite the translation technique impact, the change would naturally happens that way. As the additional translation process involving translation technique use happened, this type of transformation occurs anyway.

Table 3

The Shift of Adjunct and Complement

\begin{tabular}{l|c}
\hline \multicolumn{1}{c|}{ Type of Shift } & $\begin{array}{c}\text { Percentage } \\
(\boldsymbol{\%})\end{array}$ \\
\hline $\begin{array}{l}\text { Adjectival adjunct } \rightarrow \\
\text { Complementizer Phrase }\end{array}$ & $26 \%$ \\
\hline $\begin{array}{l}\text { Adjectival Adjunct } \rightarrow \\
\text { complement }\end{array}$ & $8 \%$ \\
\hline
\end{tabular}

This study found quite a lot of transformation, that is $26 \%$ from overall data. Meanwhile the second transformation of adjunct is a condition where it involves the translation technique use. It seems to be the opposite yet the following discussion will talk it out better.

\section{The Shift of Adjectival Adjunct to Complementizer Phrase}

The grammatical system in the target language is one of the reasons for the addition of the complementary phrases "yang". The addition of "yang" can be interpreted as a form of emphasizing on the adjective of target language. Changing attributive adjectives to complementizer phrases has two conditions of change. First, the attributive adjectives in the complementizer phrase are translated in the complete form without undergoing synthetic or lexical changes like the following example.

SL: that was a rough night

TL: itu adalah malam yang berat

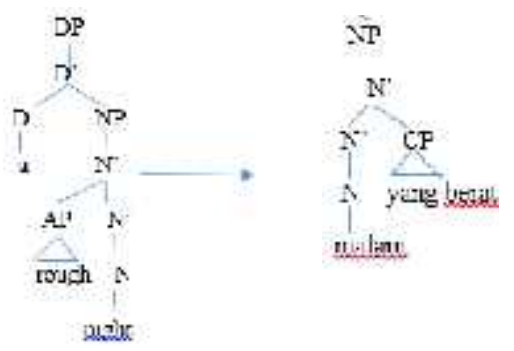

Figure 9 The Shift of Adjectival Adjunct 
The example shows that the phrase and its transformation into target language phrase involve a big part of grammatical system of different force and one omission process on the head.

English has more affixation than Indonesian. It is one of the reasons for the change of the two attributive adjectives into complementizer phrases. The following excerpt is an example of the second type of change.

SL: Heaven's Cherubim horsed upon the sightless couriers of the air"

\section{TL: bidadari di atas angin menaiki $\underline{k u d a}$}

\section{yang tak kasat mata di udara}
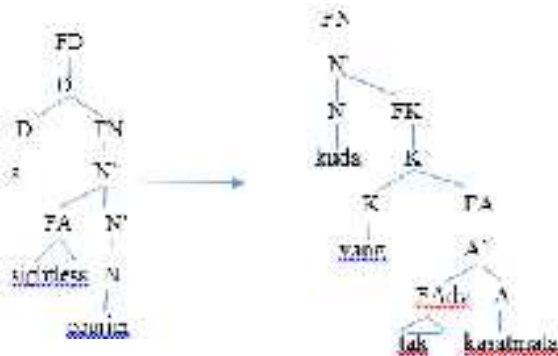

Figure 10 The Shift of Adjectival Adjunct

The complementizer phrase of the target language has a different structure to the previous changes. This study believes that the equivalent of adjective "sightless" cannot be found with just one lexical that represents the same cognitive. The target language does not have an affixation equivalent to the "_less" source language, so the translator added "tak" adverbs.

\section{The Shift of Adjectival Adjunct to Complement}

The change of adjective into complement has only one condition, that is when the head omission is on the source language phrase. With that occurrence, the adjunct and complement in the two languages will exchange positions. The following excerpt shows the adjective changes to complement.

SL: "the king of Cawdor began a dismal conflict"

TL: Raja Norwegia memulai peperangan berdarah

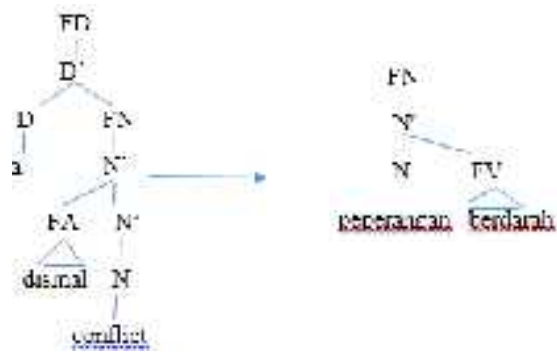

Figure 11 The Shift of Adjectival Adjunct to Complement

The grammatical transformation shows the variety of shift conducted from 50 data. Those transformations' pattern was formed by the full participation of grammatical system differences and the translation technique in the translation process. Table 4 shows the overall translation techniques use and its impact on the grammatical transformation of determiner phrase.

Table4

The Classification of Translation Techniques and its Effect on the Grammatical Shift

\begin{tabular}{l|c|c|c|c|c|c|c|c|c|c|c|c|c}
\hline \multirow{2}{*}{ Shift Form } & \multicolumn{10}{c}{ Translation Techniques } \\
\cline { 2 - 12 } & $\mathbf{1}$ & $\mathbf{2}$ & $\mathbf{3}$ & $\mathbf{4}$ & $\mathbf{5}$ & $\mathbf{6}$ & $\mathbf{7}$ & $\mathbf{8}$ & $\mathbf{9}$ & $\mathbf{1 0}$ & $\mathbf{1 1}$ & $\mathbf{1 2}$ & $\mathbf{1 3}$ \\
\hline $\begin{array}{l}\text { Adjectival } \\
\text { adjunct } \\
\text { omission }\end{array}$ & - & - & $\sqrt{ }$ & - & - & - & - & - & - & - & - & - & $\sqrt{ }$ \\
\hline $\begin{array}{l}\text { Adjunct } \\
\text { and head } \\
\text { omission }\end{array}$ & $\sqrt{ }$ & - & $\sqrt{ }$ & $\sqrt{ }$ & $\sqrt{ }$ & $\sqrt{ }$ & - & - & $\sqrt{ }$ & - & - & $\sqrt{ }$ & - \\
\hline
\end{tabular}




\begin{tabular}{l|c|c|c|c|c|c|c|c|c|c|c|c|c}
\hline $\begin{array}{l}\text { Head } \\
\text { omission }\end{array}$ & - & - & $\sqrt{ }$ & $\sqrt{ }$ & $\sqrt{ }$ & - & $\sqrt{ }$ & $\sqrt{ }$ & - & - & - & - & $\sqrt{ }$ \\
\hline $\begin{array}{l}\text { Adjunct } \rightarrow \\
\text { compleme } \\
\text { ntizer } \\
\text { phrase }\end{array}$ & - & - & $\sqrt{ }$ & $\sqrt{ }$ & $\sqrt{ }$ & - & - & $\sqrt{ }$ & - & $\sqrt{ }$ & $\sqrt{ }$ & - & $\sqrt{ }$ \\
\hline $\begin{array}{l}\text { Adjunct } \rightarrow \\
\text { compleme } \\
\text { nt }\end{array}$ & - & $\sqrt{ }$ & - & $\sqrt{ }$ & - & - & $\sqrt{ }$ & - & $\sqrt{ }$ & - & - & - & $\sqrt{ }$ \\
\hline $\begin{array}{l}\text { Compleme } \\
\text { nt h head }\end{array}$ & - & - & - & - & - & - & - & - & $\sqrt{ }$ & - & - & - & - \\
\hline $\begin{array}{l}\text { Adjunct } \\
\text { addition }\end{array}$ & - & - & - & - & - & - & - & - & - & - & - & - & $\sqrt{ }$ \\
\hline Nition
\end{tabular}

Notes: The numbers in the columns represent the thirteen techniques from left to right in the following order: adaptation, compensation, reduction, modulation, particularization, established equivalent, generalization, calque, transposition, amplification, linguistic amplification, linguistic compression, and discursive creation.

The omission only involves the adjunct and head. Adjunct could be omitted alone or it could be omitted together with the head. The significant difference of the two shows that adjunct omission is mostly caused by reduction, discursive creation and adaptation technique. Meanwhile, the omission of both adjunct and head are caused by more varied translation techniques including reduction, linguistic compression, modulation, particularization, transposition, and established equivalent. The head omission happened as the application of even more varied techniques including generalization, calque, modulation, particularization, reduction, and discursive creation.

\section{CONCLUSION}

The translation of determiner phrase shows three main grammatical transformations. They are transformation of omission, addition and shift of adjunct and complement. Each transformation represents the further break down of the type of shift. Adjunct has the most transformation including omission, addition and its shift to different form. As the result, adjunct does not only have the most grammatical transformation but also semantic transformation. It could be said that both the author and translator valued the adjectival adjunct as its role to liven up the text. Meanwhile, the complement of the phrase was never omitted. It only underwent a shift to be the head in the target text phrase. It shows that complement is the proposition of the phrase and the adjunct is the additional information semantically. The head might not become the proposition semantically, yet it has vital role in the determiner phrase transformation. It shows that the omission of the head only happened when the adjunct of ST transform into complementizer phrase of TL. The head is never to be omitted alone. It means that a phrase could have two form of shift happened within. These shifts from determiner phrases components are also partly the cause of translation technique.

\section{REFERENCES}

Artanti, R. (Ed). 2017. Macbeth. Yogyakarta: Penerbit Narasi.

Catford, J. C. (1965). A linguistic theory of translation: An essay in applied linguistics. (Vol. 8): Oxford University Press. 
Dewi, et.al. (2014). The equivalence and shift in the Indonesian translation of English adjective phrases. Research on Humanities and Social Sciences. Vol. 14 No 11(109-113).

Firdaus, A. (2014). Analisis teknik penerjemahan klausa relative pada novel "The Kite Runner" serta dampaknya terhadap kualitas hasil terjemahan. Tesis. Surakarta: Universitas Sebelas Maret Surakarta.

Munif, A. (2008). Pergeseran dalam penerjemahan klausa pasif dari novel The Lord of The Rings: "The Return of the King" oleh JRR Tolkien karya Gita Yuliani K. Tesis. Surakarta: Universitas Sebeleas Maret Surakarta.

Mabillard,

A.

(2000)

"Horatio."Shakespeare Online. (24/April/2018)

$<$ http://www.shakespeareonline.c om/playanalysis/horatiochar.html $>$.

Molina, L., \& Albir, H, (2002). A translation technique revisited: a dynamic and functionalist approach. Barcelona: Universitat Autonomade Barcelona.

Newmark, P. (1988). A textbook of translation. New York: Prentice Hall.
Newmark, P. (2001). A textbook of translation. Shanghai: Shanghai Foreign Language Education Press.

Newson, et al. (2006). Basic English syntax with exercise. Muzeum: Bölcsész.

Nurhaniah, Y.A. 2008. Terjemahan kalimat tanya dalam percakapan novel remaja "Dear Nobody" yang diterjemahkan ke dalam bahasa Indonesia. Tesis. Surakarta: Universitas Sebelas Maret Surakarta.

Rafi'ie at al. (2018). Types of Indonesian reduplication as the translation equivalence of English lexicons. Linguistika. Vol. 48, No.25(15-25).

Silalahi, R. (2016). Variation results in translating English verbs into Indonesia". International Journal of Linguistics and Communication. Vol. 4, No.1(3948).

Sneddon, J. (1996). Indonesian: A comprehensive grammar. London: Routledge.

Wulandari, A. (2017). Pergeseran klausa dalam penerjemahan karya sastra. Jurnal Linguistik Terapan. Vol.7, No. 2 (22-25). 